\title{
Use of waste canola oil as a low-cost substrate for rhamnolipid production using Pseudomonas aeruginosa
}

\author{
Beatriz Pérez-Armendáriz* (D), Carlos Cal-y-Mayor-Luna, Elie Girgis El-Kassis and Luis Daniel Ortega-Martínez
}

\begin{abstract}
Rhamnolipids are glycolipid biosurfactants that are primarily produced by Pseudomonas aeruginosa that have gained a great deal of interest for their numerous industrial applications and environmentally friendly properties. In this study, we explored the potential of waste canola oil as a low-cost and environmentally friendly substrate for the production of rhamnolipids by $P$. aeruginosa. Four different $2^{3}$ full factorial designs were used to assess the effect of three independent factors on rhamnolipid production, including carbon source (canola oil and waste canola oil), nitrogen source $\left[\left(\mathrm{NH}_{4}\right)_{2} \mathrm{SO}_{4}\right.$ and $\left.\mathrm{NaNO}_{3}\right]$ and production time (7 and 14 days). The highest observed yield was $3585.31 \pm 66.24 \mathrm{mg} / \mathrm{L}$ when P. aeruginosa was cultured for 14 days with $3 \% \mathrm{v} / \mathrm{v}$ waste canola oil and $4 \mathrm{~g} / \mathrm{L}$ of $\mathrm{NaNO}_{3}$. The nitrogen source proved to be a crucial factor, as the use of $\mathrm{NaNO}_{3}$ rather than $\left(\mathrm{NH}_{4}\right)_{2} \mathrm{SO}_{4}$ led to a 30-fold increase in production yield. The observed yield when waste canola oil was used was similar to, and even slightly higher than, that obtained using canola oil. Our results showed that waste canola oil has great potential for use as a carbon source for rhamnolipid production by P. aeruginosa, thus paving the way for the development of a low-cost, efficient, and environmentally friendly bioprocess for the production of rhamnolipids.
\end{abstract}

Keywords: Factorial design, Pseudomonas aeruginosa, Rhamnolipid, Waste canola oil

\section{Introduction}

Biosurfactants are secondary metabolites with amphiphilic properties that are produced by a variety of microorganisms (Pacwa-Plociniczak et al. 2011). These surface-active molecules have the same properties as their chemical counterparts with respect to their emulsification, detergency and foaming properties, but they are more environmentally friendly (Moya-Ramírez et al. 2015). There is increasing interest in replacing synthetic surfactants with those of biological origin (CamiliosNeto et al. 2008), the latter of which have a variety of advantages, including their ecological acceptability, low environmental toxicity, biodegradability, effectiveness, stability, and activity at high temperatures, extreme $\mathrm{pH}$ values and high salinity (George and Jayachandran 2012).

\footnotetext{
*Correspondence: beatriz.perez@upaep.mx

Department of Biological Sciences, Universidad Popular Autónoma de Estado de Puebla, 13 Poniente No. 1927, Col Barrio de Santiago, C.P. 72410 Puebla, Mexico
}

These compounds are biosynthesized when microorganisms, especially bacteria, fungi or yeast, are grown in medium containing hydrophobic compounds, such as oil or hydrocarbons (Thavasi et al. 2011). Nevertheless, biosurfactants can also be produced using alternative substrates, such as carbohydrates, glycerol or agro-industrial wastes (Wang et al. 2007).

Glycolipids are the most common biosurfactants in nature (Shoeb et al. 2013) and are formed of mono, di, tri or tetra saccharides of mannose, glucose, galactose or rhamnose that are attached to long-chain aliphatic acids with an ester or ether linkage (Rahman and Gakpe 2008). Rhamnolipids, the most studied of this class of biosurfactants, are anionic glycolipids that are formed of an L-rhamnose residue and units of $\beta$-hydroxyalkanoic acids (Müller et al. 2012). The precursors used for rhamnolipids synthesis include the nucleotide activated saccharide ATDP-L-rhamnose and hydrophobic moieties such as 3-(3-hydroxyalkanoyloxy) alkanoic acid (HAA). The sugar moiety can be synthesized from D-glucose, while 
the hydrophobic moiety can be synthesized through the fatty acid synthesis pathway, starting with twocarbon units (Chong and Li, 2017). HAA, mono- and di-rhamnolipids are almost exclusively synthesized by Pseudomonas sp. In the last decades, rhamnolipids have emerged as a promising class of biosurfactants and biotechnological products owing to their unique properties and industrials applications and may represent a sustainable alternative for traditional surfactants (Dobler et al. 2016).

Rhamnolipids have a high surface activity and emulsification index. In addition, they can be produced at relatively high yields by bacteria; further, this approach requires relatively short incubation times and uses a well understood means of production. Furthermore, because rhamnolipids are virulence factors of Pseudomonas aeruginosa, many aspects of their biosynthesis have been investigated to control their production and effects (Abdel-Mawgoud et al. 2011).

The industrial production of rhamnolipids has generated a great deal of interest due to their diverse applications in many fields (Chong and Li 2017). For example, rhamnolipids are used as whiteners and detergents because of their natural surface-active properties (Sekhon-Randhawa and Rahman 2014). Rhamnolipids are also used in bioremediation and oil recovery (Sharma et al. 2018) because of their excellent emulsification properties, which make them highly useful in removing crude oil from contaminated soils. With respect to their pharmaceutical and therapeutic applications, rhamnolipids exhibit low toxicity and have antimicrobial properties against pathogens such as Staphylococcus aureus and Listeria monocytogenes (Chen et al. 2017). In cosmetics, rhamnolipids have been shown to be effective for several skin treatments applications, such as for wound healing and the treatment of wrinkles (Sekhon-Randhawa and Rahman 2014).

Genetic factors have been shown to be a key target for the improvement of rhamnolipid production by $P$. aeruginosa (Dobler et al. 2016; Gutiérrez-Gómez et al. 2018; Huang et al. 2018). However, rhamnolipid production is highly affected by medium composition and cultivation conditions. Several studies had focused on exploring various fermentation strategies for enhancing rhamnolipid yields by optimizing fermentation parameters. For instance, compared to water-soluble carbon sources (e.g., glucose), the use of water-insoluble carbon such as vegetable oil generally produces rhamnolipids in higher titers (Chong and Li 2017). The use of factorial design to optimize culture conditions has been proven to be a successful approach to significantly increase the rhamnolipid yield obtained using several $P$. aeruginosa strains (Camilios-Neto et al. 2008; Kumar et al. 2015; Ozdal et al. 2017; El-Housseiny et al. 2019). Various studies (see Table 1) have explored economical production methods using low-cost and readily available nutrients. Carbon and nitrogen sources are among the most important parameters for rhamnolipid production, with an appropriate $\mathrm{C} / \mathrm{N}$ ratio being a key factor (Huang et al. 2018). To develop a cost-effective bioprocess, cheap nutrient sources are needed and complex mineral medium cannot be used. The use of domestic or industrial wastes for rhamnolipid production is both cost-effective and environmental-friendly (Ozdal et al. 2017).

Large amounts of waste cooking oil are produced each year in homes and restaurants and by the food industry (Chhetri et al. 2008). The improper disposal of waste cooking oil can cause serious environmental contamination as well as operational problems in sewers and water treatment plants (Panadare and Rathod 2015). However, the adequate management of waste cooking oil and its use as a feedstock to generate industrial subproducts can have economic and environmental benefits (Patil et al. 2012). Recycled waste cooking oil is primarily used as feedstock for biodiesel generation, although it has numerous other applications (Panadare and Rathod 2015). Relatively few studies have investigated the production of rhamnolipids by $P$. aeruginosa using waste cooking oils as a carbon source (see Table 1; Chong and Li 2017), and to the best of our knowledge, waste canola oil has yet to be investigated for this purpose.

The goal of this study was to evaluate the potential of waste canola oil as a cost-effective and environmentally friendly carbon source for rhamnolipid production by $P$. aeruginosa in combination with an adequate nitrogen source through a full factorial experimental design.

\section{Materials and methods \\ Molecular identification of the bacterial strain}

The $P$. aeruginosa strain used in this study was donated by a Mexican Medical laboratory (http://laboratoriosrui z.com/), where it was previously identified as $P$. aeruginosa using the Vitek 2 GN typing panel (Biomérieux, México) and analyzed using the Vitek 2 instrument (Biomérieux, México). The identity of the strain was confirmed by sequencing a portion of the $16 \mathrm{~S}$ rRNA gene with bacterial-specific primers Bacfw (ACTCCTACG GGAGGCAG) and Bacrev (GACTACCAGGGTATC TAATCC) (Yu et al. 2005). The strain was cultivated in $50 \mathrm{~mL}$ of nutritive broth (BIOXON, Mexico) for $13 \mathrm{~h}$ at $37{ }^{\circ} \mathrm{C}$ with shaking at $200 \mathrm{rpm}$. DNA extraction was performed using a QIAamp DNA Mini kit (Qiagen, Mexico) according to the manufacturer instructions. PCR amplification was performed in a reaction containing $12.5 \mu \mathrm{L}$ PrimeSTAR polymerase mix, $1 \mu \mathrm{L}$ forward primer $(10 \mu \mathrm{M}), 1 \mu \mathrm{L}$ reverse primer $(10 \mu \mathrm{M}), 4 \mu \mathrm{L}$ 
Table 1 Rhamnolipid production using $P$. aeruginosa as producer microorganism with different waste and non-waste carbon sources, nitrogen sources, culture media and production time

\begin{tabular}{|c|c|c|c|c|c|c|}
\hline $\begin{array}{l}\text { Highest } \\
\text { rhamnolipid } \\
\text { yield (g/L) }\end{array}$ & P. aeruginosa strain & Culture medium & Carbon source & Nitrogen source & Time & References \\
\hline 2.70 & 47T2 NCIB 40044 & $\begin{array}{l}\mathrm{NaNO}_{3}, \mathrm{KH}_{2} \mathrm{PO}_{4}, \\
\mathrm{~K}_{2} \mathrm{HPO}_{4}, \mathrm{KCl}, \\
\mathrm{MgSO}_{4} \cdot 7 \mathrm{H}_{2} \mathrm{O}, \mathrm{CaCl}_{2}, \\
\mathrm{FeSO}, 7 \mathrm{H}_{2} \mathrm{O}, \text { yeast } \\
\text { extract and trace } \\
\text { elements }\end{array}$ & $\begin{array}{l}40 \mathrm{~g} / \mathrm{L} \text { waste frying } \\
\text { vegetable oils }\end{array}$ & $4 \mathrm{~g} / \mathrm{L} \mathrm{NaNO}_{3}$ & $80 \mathrm{~h}$ & Haba et al. (2000) \\
\hline 1.82 & PEERO2 & $\begin{array}{l}\mathrm{KCl}, \mathrm{NaCl}, \mathrm{FeSO}_{4} \cdot 7 \mathrm{H}_{2} \mathrm{O} \\
\mathrm{KH}_{2} \mathrm{PO}_{4}, \mathrm{~K}_{2} \mathrm{HPO}_{4} \\
\mathrm{MgSO}_{4} \cdot 7 \mathrm{H}_{2} \mathrm{O} \text {, yeast } \\
\text { extract, trace ele- } \\
\text { ments }\end{array}$ & $2 \%$ v/v soy oil & $15 \mathrm{~g} / \mathrm{L} \mathrm{NaNO}_{3}$ & 4 days & Wang et al. (2007) \\
\hline 9.50 & MR01 & $\begin{array}{l}\mathrm{KH}_{2} \mathrm{PO}_{4}, \mathrm{MgSO}_{4} \cdot 7 \mathrm{H}_{2} \mathrm{O} \\
\text { yeast extract. }\end{array}$ & $4 \%$ v/v soy oil & $0.2 \% \mathrm{w} / \mathrm{v} \mathrm{NaNO} 3$ & $336 / 360 h$ & Lotfabad et al. (2010) \\
\hline 3.55 & $\mathrm{D}$ & $\begin{array}{c}\mathrm{KH}_{2} \mathrm{PO}_{4}, \mathrm{Na}_{2} \mathrm{HPO}_{4 \prime} \\
\mathrm{MgSO}_{4} \cdot 7 \mathrm{H}_{2} \mathrm{O} \text {, glyc- } \\
\text { erol, yeast extract. }\end{array}$ & $2 \%$ waste coconut oil & $6.5 \mathrm{~g} / \mathrm{L} \mathrm{NaNO}_{3}$ & 7 days & $\begin{array}{l}\text { George and Jayachan- } \\
\text { dran. (2012) }\end{array}$ \\
\hline 0.89 & PA01 & $\begin{array}{l}\text { Glucose, } \mathrm{Na}_{2} \mathrm{HPO}_{4 \prime} \\
\mathrm{KH}_{2} \mathrm{PO}_{4}, 0.4 \\
\mathrm{MgSO}_{4} \cdot 7 \mathrm{H}_{2} \mathrm{O}, \\
\mathrm{CaCl}_{2} \cdot 2 \mathrm{H}_{2} \mathrm{O}, \\
\mathrm{FeSO}_{4} \cdot 7 \mathrm{H}_{2} \mathrm{O} \text {, and } \\
\text { trace elements }\end{array}$ & $2 \%$ w/v waste oil & $2 \mathrm{~g} / \mathrm{L} \mathrm{NaNO}{ }_{3}$ & 7 days & $\begin{array}{l}\text { Moya-Ramírez et al. } \\
\text { (2015) }\end{array}$ \\
\hline 4.53 & 2297 & $\begin{array}{c}\mathrm{KH}_{2} \mathrm{PO}_{4}, \mathrm{~K}_{2} \mathrm{HPO}_{4} \\
\mathrm{MgSO}_{4} \cdot 7 \mathrm{H}_{2} \mathrm{O}\end{array}$ & $2 \%$ sawdust & $1 \mathrm{~g} / \mathrm{L}\left(\mathrm{NH}_{4}\right)_{2} \mathrm{SO}_{4}$ & $120 \mathrm{~h}$ & Kumar et al. (2015) \\
\hline 2.16 & $\begin{array}{l}\text { Local isolate (wild- } \\
\text { type) }\end{array}$ & Not specified & $1 \%$ v/v glycerol & $2 \% \mathrm{w} / \mathrm{v} \mathrm{NaNO}$ & $54 \mathrm{~h}$ & Eraqi et al. (2016) \\
\hline $4.5-5.1$ & Wild-type strain & $\begin{array}{l}\text { Oil mill wastewater } \\
(25 \% \mathrm{v} / \mathrm{v})\end{array}$ & $\begin{array}{l}\text { Corn steep liquor (10\% } \\
\text { w/v); Sugar cane } \\
\text { molasses (10\% w/v) }\end{array}$ & Not specified & & Gudiña et al. (2016) \\
\hline 2.80 & DR1 & $\begin{array}{l}\mathrm{MgSO}_{4} \cdot 7 \mathrm{H}_{2} \mathrm{O}, \mathrm{NaCl}, \mathrm{KCl} \\
\mathrm{CaCl}_{2} \cdot 2 \mathrm{H}_{2} \mathrm{O}, \mathrm{H}_{3} \mathrm{PO}_{4 \prime} \\
\text { trace elements }\end{array}$ & $\begin{array}{l}1 \% \text { mango kernel oil, } \\
1 \% \text { glucose }\end{array}$ & $2.5 \mathrm{~g} / \mathrm{L} \mathrm{NaNO}_{3}$ & $96 \mathrm{~h}$ & Sathi-Reddy et al. (2016) \\
\hline 5.00 & L05 & $\begin{array}{l}\mathrm{Na}_{2} \mathrm{HPO}_{4}, \mathrm{KH}_{2} \mathrm{PO}_{4} \\
\mathrm{~K}_{2} \mathrm{HPO}_{4} \text {, trace ele- } \\
\text { ments }\end{array}$ & $\begin{array}{l}19.43 \text { mM of myristic } \\
\text { acid }\end{array}$ & $1.4 \mathrm{~g} / \mathrm{L} \mathrm{NaNO}_{3}$ & $144 \mathrm{~h}$ & Nicolo et al. (2017) \\
\hline 5.53 & $\mathrm{AMB}$ & $\begin{array}{l}\mathrm{Na}_{2} \mathrm{HPO}_{4}, \mathrm{KH}_{2} \mathrm{PO}_{4 \prime} \\
\mathrm{NaCl} \mathrm{MgSO}_{4} \cdot 7 \mathrm{H}_{2} \mathrm{O} \\
\mathrm{CaCl}_{2} \cdot 2 \mathrm{H}_{2} \mathrm{O}\end{array}$ & $\begin{array}{l}2 \% \text { w/v waste coconut } \\
\text { oil }\end{array}$ & $0.1 \mathrm{~g} / \mathrm{L} \mathrm{NaNO}_{3}$ & $60 \mathrm{~h}$ & $\begin{array}{l}\text { Samykannu and Achary } \\
\text { (2017) }\end{array}$ \\
\hline 41.87 & $15 G R$ & $\begin{array}{l}\mathrm{MgSO}_{4} \cdot 7 \mathrm{H} 2 \mathrm{O}, \mathrm{NaCl}, \\
\mathrm{KCl} \mathrm{CaCl} \cdot 2 \mathrm{H}_{2} \mathrm{O} \\
\mathrm{H}_{3} \mathrm{PO}_{4}, \mathrm{FeSO}_{4} \cdot 7 \mathrm{H} 2 \mathrm{O}, \\
\mathrm{ZnSO}_{4} \cdot 7 \mathrm{H}_{2} \mathrm{O} \\
\mathrm{MnSO}_{4} \cdot \mathrm{H}_{2} \mathrm{O}, \mathrm{K}_{3} \mathrm{BO}_{3}, \\
\mathrm{CuSO}_{4} \cdot 5 \mathrm{H}_{2} \mathrm{O} \\
\mathrm{Na}_{2} \mathrm{MoO}_{4} \cdot 2 \mathrm{H}_{2} \mathrm{O}\end{array}$ & $2 \%$ v/v glycerol & $2.5 \mathrm{~g} / \mathrm{L} \mathrm{NaNO}_{3}$ & 6 days & El-Housseiny et al. (2019) \\
\hline
\end{tabular}

The highest rhamnolipid yield and the used P. aeruginosa strain in each case is reported

genomic DNA as template (5 ng), and $6.5 \mu \mathrm{L}$ MiliQ water. The thermocycling program was as follows: $(1) 98^{\circ} \mathrm{C}$ for 5 min, (2) $98{ }^{\circ} \mathrm{C}$ for $10 \mathrm{~s}$, (3) $58^{\circ} \mathrm{C}$ for $15 \mathrm{~s}$, (4) $72{ }^{\circ} \mathrm{C}$ for $25 \mathrm{~s}$, (5) repeat steps 2,3 and $430 \times$ and a final extension at $72{ }^{\circ} \mathrm{C}$ for $5 \mathrm{~min}$. The PCR product was purified using a QIAquick PCR Purification kit (Qiagen, Mexico) according to the manufacturer's instructions. The purified PCR product was sequenced in triplicate using the Sanger technique at the Biotechnology Institute of the National Autonomous University of Mexico). The consensus sequence was deduced from the obtained sequences using BioEdit, and the identity of the sequence was determined using the program BLAST. 


\section{Inoculum conditions}

A $500-\mathrm{ml}$ shake flask containing $100 \mathrm{~mL}$ of nutritive broth (BIOXON, Mexico) was inoculated with a 5\% (v/v) overnight culture of $P$. aeruginosa with a starting $\mathrm{OD}_{565 \mathrm{~nm}}$ of 0.012 (nutritive broth). The culture was incubated at $37{ }^{\circ} \mathrm{C}$ with shaking at $200 \mathrm{rpm}$ in a Benchmark Incu-Shaker until the optical density at $565 \mathrm{~nm}$ reached $0.745 \pm 0.020$ (corresponding to $1.53 \times 10^{8} \mathrm{CFU} / \mathrm{mL}$ ), indicating that the culture was in mid-exponential phase according to the logistic growth model (Additional file 1: Figure S1). The culture was used as an inoculum for rhamnolipid production.

\section{Factorial design}

Rhamnolipid production was optimized using four different $2^{3}$ full factorial design with three independent factors, including carbon source, nitrogen source and production time. Factorial design 1 used canola oil as a carbon source at two concentrations ( 1 and 3\%, v/v), $\left(\mathrm{NH}_{4}\right)_{2} \mathrm{SO}_{4}$ as a nitrogen source at two concentrations ( 1 and $4 \mathrm{~g} / \mathrm{L}$ ), and production times of 7 and 14 days. These 2 incubation times were selected based on previously published research where production times varied between 7 (George and Jayachandran. 2012; Moya-Ramírez et al. 2015) and 14 days (Lotfabad et al. 2010). Factorial design 2 used waste canola oil as a carbon source at two concentrations (1 and 3\%, v/v), $\left(\mathrm{NH}_{4}\right)_{2} \mathrm{SO}_{4}$ as a nitrogen source at two concentrations ( 1 and $4 \mathrm{~g} / \mathrm{L}$ ), and production times of 7 and 14 days. Factorial design 3 used canola oil as a carbon source at two concentrations ( 1 and $3 \%, \mathrm{v} / \mathrm{v}$ ), $\mathrm{NaNO}_{3}$ as a nitrogen source at two concentrations ( 1 and $4 \mathrm{~g} / \mathrm{L}$ ), and production times of 7 and 14 days. Factorial design 4 used waste canola oil as a carbon source at two concentrations ( 1 and $3 \%, \mathrm{v} / \mathrm{v}), \mathrm{NaNO}_{3}$ as a nitrogen source at two concentrations ( 1 and $4 \mathrm{~g} / \mathrm{L}$ ), and production times of 7 and 14 days. Eight experiments were performed for each factorial design in two replicates. The measured response variable was rhamnolipid production, which was expressed as rhamnose equivalents $(\mathrm{mg} / \mathrm{L})$. Sixty-four experiments in total were performed for the four different $2^{3}$ experimental designs. Minitab statistical software was used to statistically analyze the data $(p<0.05)$. Waste canola oil was obtained from a University restaurant and was filtered prior to its use to remove any particles. The experimental design is summarized in Table 2.

\section{Culture conditions}

The experiments were carried out in Erlenmeyer flasks (500 mL) containing $100 \mathrm{~mL}$ of an autoclave sterilized mineral medium containing $1 \mathrm{~g} / \mathrm{L} \mathrm{K}_{2} \mathrm{HPO}_{4}, 1 \mathrm{~g} / \mathrm{L}$
$\mathrm{KH}_{2} \mathrm{PO}_{4}$, and $0.41 \mathrm{~g} / \mathrm{L} \mathrm{MgSO}_{4} \cdot 7 \mathrm{H}_{2} \mathrm{O}$ supplemented with the corresponding carbon and nitrogen sources according to the factorial design. The culture medium was inoculated with a $5 \%(\mathrm{v} / \mathrm{v})$ of mid-exponential growth culture $\left(\mathrm{OD}_{565 \mathrm{~nm}}=0.745 \pm 0.020 ; 1.53 \times 10^{8} \mathrm{CFU} / \mathrm{mL}\right)$. The cultures were incubated at $37{ }^{\circ} \mathrm{C}$ with shaking at $200 \mathrm{rpm}$ in a Benchmark Incu-Shaker.

\section{Rhamnolipid extraction}

Rhamnolipid extraction was performed using the method described by Camilios-Neto et al. (2008) with modifications. At the end of the experiments, the culture broth was centrifuged at $5000 \mathrm{rpm}$ for $20 \mathrm{~min}$ (Hermle Labnet $\mathrm{Z}$ 326), and the supernatant was recovered and mixed with one volume of chloroform/ethanol (3:1 v/v). After mixing, phase separation was performed in a separation funnel. The lower organic phase was collected, and the process was repeated with the upper aqueous phase until no emulsification was observed. The organic phase was evaporated in a rotary evaporator (HAHNVAPOR, HS-2001NS) at $40{ }^{\circ} \mathrm{C}$, and the rhamnolipids were resuspended in one volume of distilled water.

\section{Rhamnolipid quantification}

The rhamnolipids were quantified as described by Wang et al. (2007). Briefly, a 9:1 (v/v) mixture of orcinol $(0.19 \%$ in $53 \% \mathrm{H}_{2} \mathrm{SO}_{4}$ ) and rhamnolipids sample was warmed in a water bath (Terlab, TE-B80D) at $80{ }^{\circ} \mathrm{C}$ for $30 \mathrm{~min}$. Subsequently, the sample was cooled for $10 \mathrm{~min}$ in a water bath at room temperature. The optical density was measured at $421 \mathrm{~nm}$ using a UV-Vis spectrophotometer. The rhamnolipid concentration was obtained using a standard curve of L-rhamnose $(0-50 \mathrm{mg} / \mathrm{L})$, and the results were expressed as rhamnose equivalents $(\mathrm{mg} / \mathrm{L})$. The data corresponding to Fig. 1 can be found in Additional file 1: Figure S2.

\section{Results}

Confirmation of the identity of the bacterial strain

The bacterial strain used in this study was previously identified as $P$. aeruginosa using automated biochemical tests. To confirm the identity of the strain, a partial 16S rRNA gene sequence was obtained (NCBI accession number MK307837). The sequence was analyzed using Megablast and exhibited $100 \%$ similarity with the $16 \mathrm{~S}$ rRNA gene sequences of several $P$. aeruginosa strains.

\section{Full factorial design results}

Four full factorial designs were used to evaluate the performance of waste canola oil compared with canola oil as 
Table $22^{3}$ full factorial designs used to optimize rhamnolipid production

Factorial design 1

\begin{tabular}{|c|c|c|c|}
\hline Treatment & Canola oil (\% v/v) & $\left(\mathrm{NH}_{4}\right)_{2} \mathrm{SO}_{4}(\mathrm{~g} / \mathrm{L})$ & $\begin{array}{l}\text { Production } \\
\text { time (days) }\end{array}$ \\
\hline T1 & 1 & 1 & 7 \\
\hline T2 & 3 & 1 & 7 \\
\hline T3 & 1 & 4 & 7 \\
\hline T4 & 3 & 4 & 7 \\
\hline T5 & 1 & 1 & 14 \\
\hline T6 & 3 & 1 & 14 \\
\hline $\mathrm{T7}$ & 1 & 4 & 14 \\
\hline T8 & 3 & 4 & 14 \\
\hline \multicolumn{4}{|c|}{ Factorial design 2} \\
\hline Treatment & Waste canola oil (\% v/v) & $\left(\mathrm{NH}_{4}\right)_{2} \mathrm{SO}_{4}(\mathrm{~g} / \mathrm{L})$ & $\begin{array}{l}\text { Production } \\
\text { time (days) }\end{array}$ \\
\hline T1 & 1 & 1 & 7 \\
\hline T2 & 3 & 1 & 7 \\
\hline T3 & 1 & 4 & 7 \\
\hline T4 & 3 & 4 & 7 \\
\hline T5 & 1 & 1 & 14 \\
\hline T6 & 3 & 1 & 14 \\
\hline $\mathrm{T7}$ & 1 & 4 & 14 \\
\hline T8 & 3 & 4 & 14 \\
\hline \multicolumn{4}{|c|}{ Factorial design 3} \\
\hline Treatment & Canola oil (\% v/v) & $\mathrm{NaNO}_{3}(\mathrm{~g} / \mathrm{L})$ & $\begin{array}{l}\text { Production } \\
\text { time (days) }\end{array}$ \\
\hline T1 & 1 & 1 & 7 \\
\hline T2 & 3 & 1 & 7 \\
\hline T3 & 1 & 4 & 7 \\
\hline T4 & 3 & 4 & 7 \\
\hline T5 & 1 & 1 & 14 \\
\hline T6 & 3 & 1 & 14 \\
\hline T7 & 1 & 4 & 14 \\
\hline T8 & 3 & 4 & 14 \\
\hline \multicolumn{4}{|c|}{ Factorial design 4} \\
\hline Treatment & Waste canola oil (\% v/v) & $\mathrm{NaNO}_{3}(\mathrm{~g} / \mathrm{L})$ & $\begin{array}{l}\text { Production } \\
\text { time (days) }\end{array}$ \\
\hline T1 & 1 & 1 & 7 \\
\hline T2 & 3 & 1 & 7 \\
\hline T3 & 1 & 4 & 7 \\
\hline T4 & 3 & 4 & 7 \\
\hline T5 & 1 & 1 & 14 \\
\hline T6 & 3 & 1 & 14 \\
\hline T7 & 1 & 4 & 14 \\
\hline T8 & 3 & 4 & 14 \\
\hline
\end{tabular}



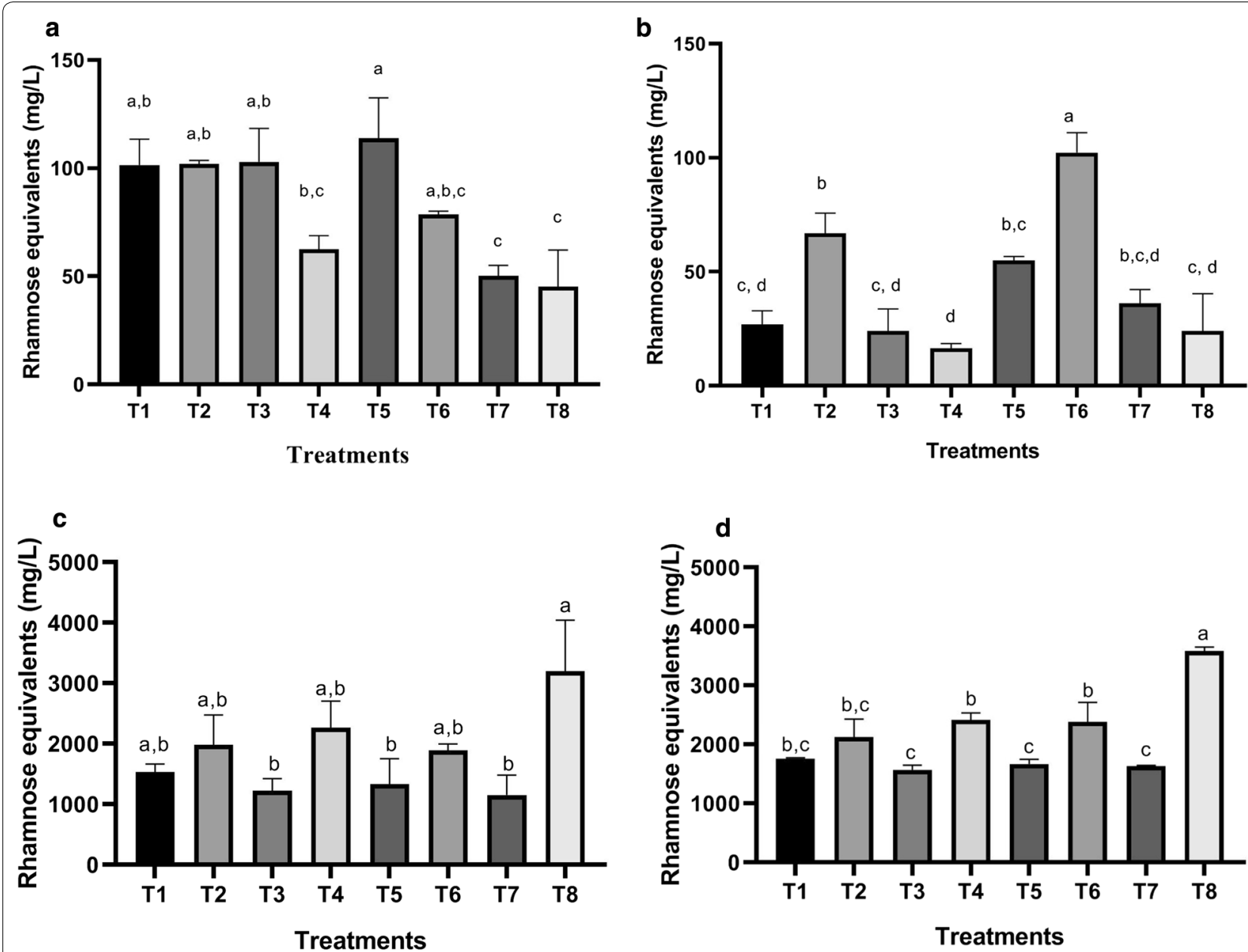

Fig. 1 The four full factorial designs used to optimize rhamnolipid production. The rhamnolipid yield is expressed as rhamnose equivalents. a Factorial design 1 (Canola Oil/( $\left.\left(\mathrm{NH}_{4}\right)_{2} \mathrm{SO}_{4}\right)$; b Factorial design 2 (Waste canola Oil/( $\left.\left.\mathrm{NH}_{4}\right)_{2} \mathrm{SO}_{4}\right)$; c Factorial design $3(\text { Canola Oil/( } \mathrm{NaNO})_{3}$; d Factorial design 4 (Waste canola Oil/( $\left(\mathrm{NaNO}_{3}\right)$. Treatments that do not share a letter are significantly different $(p<0.05)$

well as to determine the optimal nitrogen source, carbon/ nitrogen ratio and production time (Fig. 1).

When canola oil and ammonium sulfate were used as carbon and nitrogen sources, respectively (Factorial design 1; Fig. 1a), no significant differences in rhamnolipid yields $(p<0.05)$ were observed between treatments 1, 2, 3, 5 and 6 . The highest rhamnolipid yield was observed for treatment $5(113.83 \pm 18.69 \mathrm{mg} / \mathrm{L})$. Upon switching the carbon source to waste canola oil, while the nitrogen source remained ammonium sulfate (Factorial design 2; Fig. 1b), treatment 6 (High carbon, low nitrogen, 14 days) showed the highest rhamnolipid yield $(102.24 \pm 8.66 \mathrm{mg} / \mathrm{L})$.

When canola oil and sodium nitrate were used as carbon and nitrogen sources, respectively (Factorial design 3; Fig. 1c), the highest rhamnolipid yield $(3196.33 \pm 848.05 \mathrm{mg} / \mathrm{L})$ was obtained for treatment 8 (high carbon and nitrogen, 14 days) and was significantly different from the other treatments. Upon switching the carbon source to waste canola oil, while the nitrogen source remained as sodium nitrate (Factorial design 4; Fig. 1d), the highest rhamnolipid yield $(3585.31 \pm 66.24 \mathrm{mg} / \mathrm{L})$ was also observed with treatment 8 and was significantly different from the other treatments. The highest yield among the 32 treatments of the 4 factorial designs was obtained for treatment 8 of factorial design 4.

The use of sodium nitrate as a nitrogen source (factorial designs 3 and 4) led to a 30-fold increase in rhamnolipid yield under all treatments (Fig. 1c, d) compared to the yield obtained when ammonium nitrate was used as a nitrogen source (factorial designs 1 and 2; Fig. 1a, b). The rhamnolipid yield obtained when waste canola oil was used as a carbon source (Fig. 1d) was comparable and even slightly higher than the yield observed when canola oil was used as a carbon source (Fig. 1c). 


\section{Discussion}

The $P$. aeruginosa strain used in this study was a wildtype clinical isolate that was previously identified using biochemical tests. Partial sequencing of the $16 \mathrm{~S}$ rRNA gene in combination with the biochemical tests results enabled the confirmation of the identity of the strain as $P$. aeruginosa. This species is considered a metabolically versatile bacterium that is able to use a variety of simple and complex carbon sources and can survive under normal and harsh environmental conditions (Rojo 2010; El-Housseiny et al. 2019). These characteristics make $P$. aeruginosa an excellent candidate for rhamnolipid production using unusual carbon sources.

The results of numerous reports indicate that rhamnolipid production by $P$. aeruginosa is dependent on medium components in addition to other factors (Mulligan and Gibbs 1989; Müller et al. 2012; El-Housseiny et al. 2016, Gutiérrez-Gómez et al. 2018), with carbon and nitrogen sources being among the most important factors to be considered (Huang et al. 2018). To determine the potential of waste canola oil as a carbon source for rhamnolipid production, we used a factorial design to determine the effect of 3 parameters, carbon source (canola oil and waste canola oil), nitrogen source (ammonium sulfate and sodium nitrate) and production time (7 and 14 days) as well as the interaction between these parameters (Table 2). The results presented in Fig. 1 show that when ammonium nitrate was used as a nitrogen source, rhamnolipid production remained low regardless of the carbon source and production time used, with canola oil faring slightly better than waste canola oil (Fig. 1a, b). However, when the nitrogen source was switched to sodium nitrate a 12 to 30 -fold increase in rhamnolipid production was observed (Fig. 1c, d). This result is in agreement with previously published reports. Most studies favor the use of nitrate over ammonium as a nitrogen source for rhamnolipid production by $P$. aeruginosa (see Table 1 ). Furthermore, it was shown that under certain experimental conditions, sodium nitrate promotes rhamnolipid production, whereas ammonium sulfate inhibits it (Mulligan and Gibbs 1989). However, alternative nitrogen sources should not be entirely discounted, as they may still be useful under certain circumstances (Huang et al. 2018), including ammonium sulfate (Kumar et al. 2015). Thus, the best course of action is to determine the nitrogen source that pairs best with the desired carbon source to maximize rhamnolipid yield.

When sodium nitrate was used as a nitrogen source, waste canola oil (Fig. 1d) performed as well and even slightly better than canola oil (Fig. 1c), particularly under experimental conditions using high concentrations of carbon and nitrogen, and 14 days of production (treatment T8, Fig. 1c, d). The maximum rhamnolipid yield attained under these conditions $(3.6 \mathrm{~g} / \mathrm{L}$ for waste canola oil and $3.2 \mathrm{~g} / \mathrm{L}$ for canola oil) is comparable to that obtained by other studies using a variety of different carbon sources (see Table 1), particularly when the use of submerged fermentation conditions and wild-type strains are considered. These results indicates that waste canola oil has excellent potential as a carbon source for the production of rhamnolipids by $P$. aeruginosa. Importantly, only three parameters were considered in our study for the optimization of culture conditions (carbon source, nitrogen source and production time). Thus, additional improvements could be made in the rhamnolipid yield obtained using waste canola oil as a carbon source through the optimization of other important bioprocess parameters, such as $\mathrm{pH}$, incubation temperature and dissolved oxygen among others (Zhu et al. 2012; Müller et al. 2012; Bazsefidpar et al. 2019).

The fact that the highest rhamnolipid yield was obtained for treatment 8 for factorial designs 3 (Fig. 1c) and 4 (Fig. 1d) suggests that the $\mathrm{C} / \mathrm{N}$ ratio under these experimental conditions is the closest to the optimal $\mathrm{C} / \mathrm{N}$ ratio when canola or waste canola oil is used as a carbon source and sodium nitrate is used as a nitrogen source. Interestingly, when rhamnolipid production time was set to 7 days (treatments 1, 2, 3 and 4), the highest yield was obtained for treatment 4 that have the same $\mathrm{C} / \mathrm{N}$ ratio as treatment 8 , regardless of the used carbon source (Fig. 1c, d). Both treatments 4 and 8 feature the highest carbon and nitrogen contents but differ by the production times: 7 and 14 days respectively (Table 1 ). The fact that the rhamnolipid yield was higher for treatment 8 as compared to treatment 4 suggests that both carbon and nitrogen sources where limiting for all other treatments. These results suggest that further improvements of rhamnolipid yield could be made through the optimization of the $\mathrm{C} / \mathrm{N}$ ratio and the used carbon and nitrogen substrates concentration.

When vegetable oil is fried, it undergoes several types of chemical degradation reactions that result in a change in its fatty acid composition and physicochemical characteristics, including hydrolysis, oxidation and polymerization (Choe and Min 2007). The first two reactions lead to an increase in the free fatty acid content of the oil and a decrease in the degree of unsaturation of fatty acids, respectively. These reactions are correlated with the greater acid value and higher viscosity observed with used cooking oil compared with unused vegetable oil (Chhetri et al. 2008; Knothe and Steidley 2009). Knothe and Steidley (2009) observed an overall increase in the saturation of fatty acids in used vegetable oils compared to the corresponding oil before use, with an observed increase in stearic (C18:0) and oleic (C18:1) acids and a decrease 
in linoleic (C18:2) and linolenic (C18:3) acids. Huang et al. 2018 tested various vegetable oils as carbon sources for rhamnolipid production, including palm, olive, rapeseed (canola), soybean and corn oils. Their results showed that olive oil was the carbon source that produced the highest rhamnolipid yield under their experimental conditions. Since oleic acid is by far the most abundant fatty acid in olive oil (Gunstone 1996), their results might indicate a preference of $P$. aeruginosa for oleic acid. Canola oil has a typical fatty acid composition of approximately $60 \%$ oleic acid, $20 \%$ linoleic acid and $10 \%$ linolenic acid (Warner and Mounts 1993). In contrast, olive oil generally has a higher content of oleic acid (78\%) and a lower content of linoleic (7\%) and linolenic (1\%) acids than canola oil (Gunstone 1996). When canola oil is fried, an increase in oleic acid and a decrease in linoleic and linolenic acid contents would confer a fatty acid profile to the waste canola oil that is globally similar to that of unused olive oil. This phenomenon may explain the increase in rhamnolipid production when waste canola oil is used as a carbon source (Fig. 1d) compared to the yield obtained with unused canola oil (Fig. 1c). The increase in free fatty acid content in waste cooking oil would be challenging for any bacterial species due to its antibacterial effects (Yoon et al. 2018). However, P. aeruginosa is resistant to most free fatty acids other than eicosapentaenoic acid (C20:5), making $P$. aeruginosa particularly suitable for rhamnolipid production using waste cooking oil.

It is particularly noteworthy that the rhamnolipid yield attained in this study was achieved using a mineral medium that contained only four salts $\left(\mathrm{K}_{2} \mathrm{HPO}_{4}\right.$, $\mathrm{KH}_{2} \mathrm{PO}_{4}, \mathrm{MgSO}_{4}$ and $\mathrm{NaNO}_{3}$ ) included waste canola oil as the sole carbon source. This medium is considered minimal when compared to the composition of the more complex growth media used in other studies (see Table 1). Along with cost reductions due to the use of waste canola oil as a carbon source, the use of a simplified mineral medium should lead to further cost reductions upon scaling-up the bioprocess. High production costs are one of the major obstacles facing the large-scale industrial production of biosurfactants (Müller et al. 2012; Chong and Li 2017). Thus, increasing the rhamnolipid yield should be pursued in parallel with the development of low-cost substrates and growth media to increase the economic and technical feasibility of the industrial production of biosurfactants.

\section{Additional files}

Additional file 1. Additional figures.

Additional file 2. Additional tables.
Authors' contributions

BPA and $C C L$ conceived and designed experiments. $C C L$ and BPA performed the optimization of biosurfactant production experiments. CCL and EGK performed the molecular experiments. CCL and LDOM performed the statistical analysis. All authors contributed to writing and reviewing the final manuscript. All authors read and approved the final manuscript.

\section{Acknowledgements}

We are grateful for the Research Department of the Universidad Popular Autónoma del Estado de Puebla for their support of this project.

\section{Competing interests}

The authors declare that they have no competing interests.

\section{Availability of data and materials}

The dataset supporting the conclusions of this article is included within the article. All data are fully available without restriction.

\section{Consent for publication \\ Not applicable.}

Ethics approval and consent to participate

Not applicable.

\section{Funding}

This work was supported by the Research Department of the Universidad Popular Autónoma del Estado de Puebla (Project No. 30108-1024).

\section{Publisher's Note}

Springer Nature remains neutral with regard to jurisdictional claims in published maps and institutional affiliations.

Received: 30 January 2019 Accepted: 25 April 2019

Published online: 06 May 2019

\section{References}

Abdel-Mawgoud AM, Hausmann R, Lépine F, Müller MM, Déziel E (2011) Rhamnolipids: detection, analysis, biosynthesis, genetic regulation, and bioengineering of production. In: Soberón-Chávez G (ed) biosurfactants from genes to application, 1st edn. Springer-Verlag, Berlin

Bazsefidpar S, Mokhtarani B, Panahi R, Hajfarajollah H (2019) Overproduction of rhamnolipid by fed-batch cultivation of Pseudomonas aeruginosa in a lab-scale fermenter under tight DO control. Biodegradation 30(1):59-69. https://doi.org/10.1007/s10532-018-09866-3

Camilios-Neto D, Meira JA, de Araújo MJ, Mitchell DA, Krieger N (2008) Optimization of the production of rhamnolipids by P. aeruginosa UFPEDA 614 in solid-state culture. Appl Microbiol Biotechnol 81(3):441-448. https://doi. org/10.1007/s00253-008-1663-3

Chen J, Wu Q, Hua Y, Chen J, Zhang H, Wang H (2017) Potential applications of biosurfactant rhamnolipids in agriculture and biomedicine. Appl Microbiol Biotechnol 101(23-24):8309-8319. https://doi.org/10.1007/ s00253-017-8554-4

Chhetri AB, Watts KC, Rafiqul Islam M (2008) Waste cooking oil as an alternate feedstock for biodiesel production. Energies 1:3-18. https://doi. org/10.3390/en1010003

Choe E, Min D (2007) Chemistry of deep-fat frying oils. J Food Sci 72:77-86. https://doi.org/10.1111/j.1750-3841.2007.00352.x

Chong H, Li Q (2017) Microbial production of rhamnolipids: opportunities, challenges and strategies. Microb Cell Fact 16(1):137. https://doi. org/10.1186/s12934-017-0753-2

Dobler L, Vilela LF, Almeida RV, Neves BC (2016) Rhamnolipids in perspective: gene regulatory pathways, metabolic engineering, production and technological forecasting. N Biotechnol 22(1):123-135. https://doi. org/10.1016/j.nbt.2015.09.005

El-Housseiny GS, Aboshanab KM, Aboulwafa MM, Hassouna NA (2016) Optimization of rhamnolipid production by P. aeruginosa isolate P6. J Surfact Deterg 19:943-955. https://doi.org/10.1007/s11743-016-1845-4 
El-Housseiny GS, Aboshanab KM, Aboulwafa MM, Hassouna NA (2019) Rhamnolipid production by a gamma ray-induced Pseudomonas aeruginosa mutant under solid state fermentation. AMB Express. 9(1):7. https://doi. org/10.1186/s13568-018-0732-y

Eraqi WA, Yassin AS, Ali AE, Amin MA (2016) Utilization of crude glycerol as a substrate for the production of rhamnolipid by P. aeruginosa. Biotechnol Res Int 2016:3464509. https://doi.org/10.1155/2016/3464509

George S, Jayachandran K (2012) Production and characterization of rhamnolipid biosurfactant from waste frying coconut oil using a novel $P$. aeruginosa D. J Appl Microbiol 114:373-383. https://doi.org/10.1111/ jam.12069

Gudiña EJ, Rodrigues Al, de Freitas V, Azevedo Z, Teixeira JA, Rodrigues LR (2016) Valorization of agro-industrial wastes towards the production of rhamnolipids. Bioresour Technol 212:144-150. https://doi.org/10.1016/j. biortech.2016.04.027

Gunstone FD (1996) Fatty acid and lipid chemistry. Springer, Boston. https:// doi.org/10.1007/978-1-4615-4131-8

Gutiérrez-Gómez U, Soto-Aceves MP, Servín-González L, Soberón-Chávez G (2018) Overproduction of rhamnolipids in Pseudomonas aeruginosa PA14 by redirection of the carbon flux from polyhydroxyalkanoate synthesis and overexpression of the rhIAB-R operon. Biotechnol Lett 40(11-12):1561-1566. https://doi.org/10.1007/s10529-018-2610-8

Haba E, Espuny MJ, Busquets M, Manresa A (2000) Screening and production of rhamnolipids by Pseudomonas aeruginosa 47T2 NCIB 40044 from waste frying oils. J Appl Microbiol 88(3):379-387

Huang C, Li Y, Tian Y, Hao Z, Chen F, Ma Y (2018) Enhanced rhamnolipid production of Pseudomonas aeruginosa DN1 by metabolic engineering under diverse nutritional factors. J Pet Environ Biotechnol 9(5):384. https ://doi.org/10.4172/2157-7463.1000384

Knothe G, Steidley KR (2009) A comparison of used cooking oils: a very heterogeneous feedstock for biodiesel. Bioresour Technol 100(23):5796-5801. https://doi.org/10.1016/j.biortech.2008.11.064

Kumar AP, Janardhan A, Radha S, Viswanath B, Narasimha G (2015) Statistical approach to optimize production of biosurfactant by P. aeruginosa 2297 3 Biotech 5(1):71-79. https://doi.org/10.1007/s13205-014-0203-3

Lotfabad TB, Abassi H, Ahmadkhaniha R, Roostaazad R, Masoomi F, Zahiri HS, Ahmadian G, Vali H, Noghabi KA (2010) Structural characterization of rhamnolipid-type biosurfactant produced by P. aeruginosa MR01: enhancement of di-rhamnolipid proportion using gamma irradiation. Colloids Surf B Biointerfaces 81(2):397-405. https://doi.org/10.1016/j. colsurfb.2010.06.026

Moya-Ramírez I, Tsaousi K, Michelle R, Marchant R, Jurado-Alameda E, GarcíaRoman M, Banat IM (2015) Rhamnolipid and surfactin production from olive oil mil waste as sole carbon source. Bioresour Technol 198:231-236. https://doi.org/10.1016/j.biortech.2015.09.012

Müller MM, Kügler J, Henkei M, Melanie G, Hörmann B, Pöhnlein M, Syldatk C, Hausmann R (2012) Rhamnolipids - next generation surfactants? J Biotechnol 162(4):366-380. https://doi.org/10.1016/j.jbiotec.2012.05.022

Mulligan CN, Gibbs BF (1989) Correlation of nitrogen metabolism with biosurfactant production by Pseudomonas aeruginosa. Appl Environ Microbiol 55(11):3016-3019

Nicolo MS, Cambria MG, Impallomeni G, Rizzo MG, Pellicorio C, Ballistreri A, Guglielmino SPP (2017) Carbon source effects on the mono/dirhamnolipid ratio produced by $P$ aeruginosa L05, a new human respiratory isolate. N Biotechnol 39(2):36-41. https://doi.org/10.1016/j.nbt.2017.05.013

Ozdal M, Gurkok S, Ozdal OG (2017) Optimization of rhamnolipid production by $P$. aeruginosa OG1 using waste frying oil and chicken feather peptone. 3 Biotech 7(2):117. https://doi.org/10.1007/s13205-017-0774-x

Pacwa-Plociniczak M, Plaza GA, Piotrowska-Seget Z, Cameotra SS (2011) Environmental applications of biosurfactants: recent advances. Int J Mol Sci 12(1):633-654. https://doi.org/10.3390/ijms12010633

Panadare DC, Rathod VK (2015) Applications of waste cooking oil other than biodiesel: a review. IJChE 12(3):55-76
Patil PD, Gude VG, Reddy HK, Muppaneni T, Deng S (2012) Biodiesel production from waste cooking oil using sulfuric acid and microwave irradiation processes. J Environ Prot 3(1):107. https://doi.org/10.4236/jep.2012.31013

Rahman PKSM, Gakpe E (2008) Production, characterization and applications of biosurfactants-review. Biotechnol 7(2):360-370. https://doi. org/10.3923/biotech.2008.360.370

Rojo F (2010) Carbon catabolite repression in Pseudomonas: optimizing metabolic versatility and interactions with the environment. FEMS Microbiol Rev 34(5):658-684. https://doi.org/10.1111/j.1574-6976.2010.00218.x

Samykannu M, Achary A (2017) Utilization of agro-industry residue for rhamnolipid production by P. aeruginosa AMB AS7 and its application in chromium removal. Appl Biochem Biotechnol 183(1):70-90. https://doi. org/10.1007/s12010-017-2431-6

Sathi-Reddy K, Yahya-Khan M, Archana K, Reddy G, Hameeda B (2016) Utilization of mango kernel oil for the rhamnolipid production by $P$. aeruginosa DR1 towards its application as biocontrol agent. Bioresour Technol 221:291-299. https://doi.org/10.1016/j.biortech.2016.09.041

Sekhon-Randhawa KK, Rahman P (2014) Rhamnolipid biosurfactants_past, present, and future scenario of global market. Front Microbiol 5:454. https ://doi.org/10.3389/fmicb.2014.00454

Sharma R, Singh J, Verma N (2018) Optimization of rhamnolipid production from Pseudomonas aeruginosa PBS towards application for microbial enhanced oil recovery. 3 Biotech 8(1):20. https://doi.org/10.1007/s1320 5-017-1022-0

Shoeb E, Akhlaq F, Badar U, Akhter J, Imtiaz S (2013) Classification and industrial applications of biosurfactants. SAVAP Int. 4(3):243-252

Thavasi R, Sharma S, Jayalakshmi S (2011) Evaluation of screening methods for the isolation of biosurfactant producing marine bacteria. J Pet Environ Biotechnol S 1:001. https://doi.org/10.4172/2157-7463

Wang Q, Fang X, Bai B, Liang X, Shuler PJ, Goddard WA III, Tang Y (2007) Engineering bacteria for production of rhamnolipid as an agent for enhanced oil recovery. Biotechnol Bioeng 98(4):842-853. https://doi.org/10.1002/ bit.21462

Warner K, Mounts TL (1993) Frying stability of soybean and canola oils with modified fatty acid compositions. J Am Oil Chem Soc 70(10):983-988. https://doi.org/10.1007/BF02543024

Yoon BK, Jackman JA, Valle-González ER, Cho N-J (2018) Antibacterial free fatty acids and monoglycerides: biological activities, experimental testing, and therapeutic applications. Int J Mol Sci 19(4):1114. https://doi.org/10.3390/ ijms19041114

Yu Y, Lee C, Kim J, Hwang S (2005) Group-specific primer and probe sets to detect methanogenic communities using quantitative real-time polymerase chain reaction. Biotechnol Bioeng 89(6):670-679. https://doi. org/10.1002/bit.20347

Zhu L, Yang X, Xue C, Chen Y, Qu L, Lu W (2012) Enhanced rhamnolipids production by Pseudomonas aeruginosa based on a pH stage-controlled fed-batch fermentation process. Bioresour Technol 117:208-213. https:// doi.org/10.1016/j.biortech.2012.04.091

\section{Submit your manuscript to a SpringerOpen ${ }^{\circ}$ journal and benefit from:}

- Convenient online submission

- Rigorous peer review

- Open access: articles freely available online

- High visibility within the field

- Retaining the copyright to your article

Submit your next manuscript at $\mathbf{s p r i n g e r o p e n . c o m ~}$ 